Brit. J. vener. Dis. (1957), 33, 223.

\title{
NON-GONOCOCCAL URETHRITIS
}

\section{AN INVESTIGATION TO DETERMINE FACTORS IN THE HOST INFLUENCING RESPONSE TO TREATMENT AND RECURRENCE OF SYMPTOMS*}

\author{
BY \\ R. S. MORTON \\ Stockport and East Cheshire \\ AND \\ LUCIEN READ \\ Blackburn and Burnley
}

Non-gonococcal urethritis (NGU), an inflammation of the male urethra, usually following sexual intercourse, is of unknown aetiology. The diagnosis is usually made by the exclusion of the gonococcus. The condition appears to be becoming increasingly common in all parts of the world. Ministry of Health returns, since the disease became separately classified in 1951, certainly show that it has become more common in England and Wales; viz. 1951, 10,$794 ; 1952,11,552 ; 1953,13,157 ; 1954,13,279$; $1955,14,269$.

Except for 3 or 4 per cent. of the men who develop incomplete or complete Reiter's syndrome (urethritis, polyarthritis, conjunctivitis, and keratodermia blennorrhagica,) the outlook is fairly good. Whether or not the condition is truly venereal raises problems in individual cases, and certainly in married men, where considerable domestic disharmony may be precipitated. Further, as Wolf, Thoshinsky, Chodosh, and Arrington (1956) have said, the assurance of cure cannot be optimistically given.

The list of possible causes is only equalled by the number of suggested treatments. Organisms found in Gram-stained smears and cultures are now generally accepted as contaminants, saprophytes, and/or commensals (Kirby, Bucca, and Thayer, 1950; Melen and Linnros, 1952; Nicol and Edward, 1953). Attempts to incriminate the Trichomonas vaginalis have so far failed in all but a few cases (Liston and Lees, 1940; Freed, 1945, 1948; Lanceley and McEntegart, 1953; Lancet, 1954; Sorel, 1954). Intracellular inclusions have been described, but attempts to find a virus have met with no success (Willcox, 1954a, b; Ford, 1956). Odium albicans has been suggested by Auckland and Preston (1954), but remains unsupported. Likewise, spirochaetes found in the centrifuged urine from cases of NGU

\footnotetext{
* Received for publication June 4, 1957.
}

by Coutts (1948) are not favoured as a likely cause. Grimble and Czonka (1955) have described skin tests which go a long way to support the idea that NGU is an infective condition. Almost all workers are in agreement that all alleged causes are unproven, and that the true aetiology remains to be determined.

As the cause is unknown, all treatment must be regarded as symptomatic or empirical. Many cases will clear spontaneously without treatment, as shown by Gartman and Leibovitz (1955), who found that in $62(58.5$ per cent.) out of 106 untreated controls, the symptoms subsided spontaneously within 8 weeks. This, however, is of little comfort to the anxious patient, and most venereologists take active steps to clear the condition as soon as possible. Of recent years, antibiotics have formed the main standby, and each has been tried as it has become available. The figures given by Harkness (1953) reflect what is generally found by way of response. With chloramphenicol, aureomycin, and terramycin, he used doses of $500 \mathrm{mg}$. 6-hrly for 4 days, and occasional extensions of this routine; with streptomycin he used $1 \mathrm{~g}$. daily for 5 days (Table I).

TABLE I

RESPONSE RATES, ACCORDING TO HARKNESS (1953)

\begin{tabular}{|c|c|c|c|c|c|}
\hline \multicolumn{2}{|l|}{ Treatment } & $\begin{array}{c}\text { Strepto- } \\
\text { mycin }\end{array}$ & $\begin{array}{l}\text { Chloram- } \\
\text { phenicol }\end{array}$ & $\begin{array}{c}\text { Aureo- } \\
\text { mycin }\end{array}$ & $\begin{array}{l}\text { Teria- } \\
\text { mycin }\end{array}$ \\
\hline \multicolumn{2}{|c|}{ No. Treated } & $146(39)$ & 89 (39) & $302(39)$ & 199 (39) \\
\hline \multirow{2}{*}{ Successes } & No. . . & $57(15)$ & $31(12)$ & $191(23)$ & $172(34)$ \\
\hline & Per cent. & $39(38)$ & $36(31)$ & 43 (59) & $86(87)$ \\
\hline
\end{tabular}

(Random treatment series in brackets)

More recently, Willcox (1954a, b, 1956) has described the use of erythromycin and spiromycin in the treatment of NGU; he achieved a response rate of 66 per cent. and 78 per cent. respectively, 
but the number of patients concerned was very small. The treatment given by Lyall (1953), consisting of a combined course of a $1 \mathrm{~g}$. injection of streptomycin and $30 \mathrm{~g}$. sulphathiazole over 5 days, gave a response rate of 85.4 per cent. in his hands.

Not all workers are agreed, however, that any of the above schedules represents the last word in treatment. Kershaw and Lindsay (1956), following a study of 378 cases, considered NGU to be a problem of management rather than of repeated courses of antibiotics. Prebble (1957) considered antibiotic therapy an unnecessary and unjustifiable expense, and claimed that 85 per cent. of cases could be cured in a few days with irrigations of $1 / 4000$ mercury oxycyanide. He found this compared favourably with his 78 per cent. response to combined streptomycin and sulphathiazole, and with a 65 per cent. response to erythromycin. For many years, potassium citrate mixture, as recommended by Liston and Lees (1940), has been a regular standby. It is generally held that the urine-alkalinizing property of this mixture is itself corrective. Others believe that alkalinizing the urine leads to symptomatic relief from dysuria only, the urethral discharge in such cases clearing spontaneously.

The question of the recurrence of NGU is a difficult one. On the whole, the available literature throws little light on the problem and discussion centres in the aspects of relapse or re-infection. The answer in the individual case is always a matter for surmise. There is as yet no well-defined group of tests of cure in NGU. Kershaw and Lindsay (1956) found that seventy (18.5 per cent.) of their 387 cases had a recurrence of the urethral discharge within 3 months of treatment. In about half of these they thought that alcohol, trauma, and/or fresh exposure had played a part, but they were unable to give an explanation for recurrence in the remainder. Harkness (1953) considered most recurrences to be due to re-infection. He treated 41 female consorts empirically with aureomycin or terramycin and in only one man was there any recurrence.

\section{Present Study}

Considering the enigmatic nature of NGU and its response to treatment, we have reviewed our cases during the 5-year period, July, 1951 to June, 1956 , to see if any of the basic details known about the men provided any criteria regarding their chances of response to the treatment. We have also reviewed our cases of recurrence in like manner. During this period the diagnosis of NGU was made 467 times. As we are concerned in this study with attacks of NGU, the total of "infections" studied exceeds the actual number of patients.
Clinical Picture.-As regards the clinical findings, 460 presented with a complaint of urethral discharge. Dysuria to any degree was not a common finding, occuring only in 109 ( 23 per cent.). It presented mainly as burning micturition, irritation at the meatus, and perineal discomfort. Fourteen ( 3 per cent.) presented with or developed Reiter's syndrome; in three, the syndrome was complete. Epididymitis was a presenting symptom, or developed, in six patients (1 per cent.).

Treatment.-Our routine forms of treatment have, of course, changed over the years. The following have been standard:

(1) Potassium citrate mixture four times a day, with an abundance of fluids.

(2) Sulphonamides as Sulphatriad, 5 g. per day for 5 days. In addition, almost all patients were also treated with potassium citrate mixture.

(3) Streptomycin 1 g. intramuscularly daily for 4 days. It was the practice to combine potassium citrate mixture four times a day with this therapy, Abraham and Duthie (1946) having shown that streptomycin activity is increased by alkalinizing the urine.

(4) Chloramphenicol $250 \mathrm{mg}$. 6-hrly for 4 days.

(5) Aureomycin $250 \mathrm{mg}$. 6-hrly for 4 days.

(6) Terramycin $250 \mathrm{mg}$. 6-hrly for 4 days.

Results.-Where one form of treatment failed, another was immediately ordered. 28 patients failed to respond to any of these treatments but later responded to irrigations with $1 / 4000$ mercury oxycyanide and/or prostatic massage.

In eight patients the urethral discharge cleared spontaneously during the course of investigation. Six patients were seen and diagnosed, but were transferred to care elsewhere, before the effects of treatment could be judged. Another 25 patients defaulted immediately, i.e. they attended only once and no estimate of the effect of treatment could be made. It could be taken that these patients defaulted because they were "cured", but we feel that this assumption is not wholly justified.

If therefore these 39 patients are discounted we are left with a working total of 428 cases of NGU who received 586 courses of treatment (Table II, opposite) which produced a response in 400 cases, an overall success rate of 68 per cent.

Side-Effects.-Twenty patients complained of looseness of the bowels usually passing three or four motions a day. Some of these had anal irritation and/or anal rash. These side-effects occurred almost exclusively with aureomycin or terramycin; streptomycin caused side-effects in only one case. Four of the patients complaining of side-effects had had concomitant vitamin "B" complex orally. 
TABLE II

RESPONSE RATES, ACCORDING TO MORTON AND READ

\begin{tabular}{|c|c|c|c|c|c|c|c|c|c|}
\hline Treatment & . & . & . & Potassium Citrate Mixture & Sulphatriad & Streptomycin & Chloramphenicol & Aureomycin & Terramycin \\
\hline No. Treated & $\cdots$ & $\ldots$ & $\cdots$ & 119 & 109 & 103 & 19 & 62 & 174 \\
\hline \multirow{2}{*}{ Successes } & No. & $\cdots$ & $\cdots$ & 58 & 60 & 73 & 14 & 47 & 148 \\
\hline & \multicolumn{2}{|c|}{ Per cent. } & $\ldots$ & 48 & 55 & 70 & 73 & 76 & 85 \\
\hline
\end{tabular}

Follow-up.-The 428 cases were seen at least once after completing the course of therapy to which they were showing a response. 360 (85 per cent.) were followed for a week or more; 322 ( 75 per cent.) for 2 weeks or more; 244 ( 57 per cent.) for 4 weeks or more; 105 (24 per cent.) for 9 weeks or more.

In 345 ( 80 per cent.), the discharge had cleared completely within 14 days of finishing whatever course of treatment prompted response. 73 took longer than 14 days, and in ten cases the patient was showing a good response when last seen. In most cases, the urine cleared as soon as the discharge disappeared, but threads in the urine persisted in some for a further 2 or 3 weeks.

As a next step we studied our patients to see if there was any difference in the response rate which might be due to age, occupation, marital status,

TABLE III

PERCENTAGE SUCCESS ACCORDING TO PERSONAL DETAILS AND CLINICAL FINDINGS

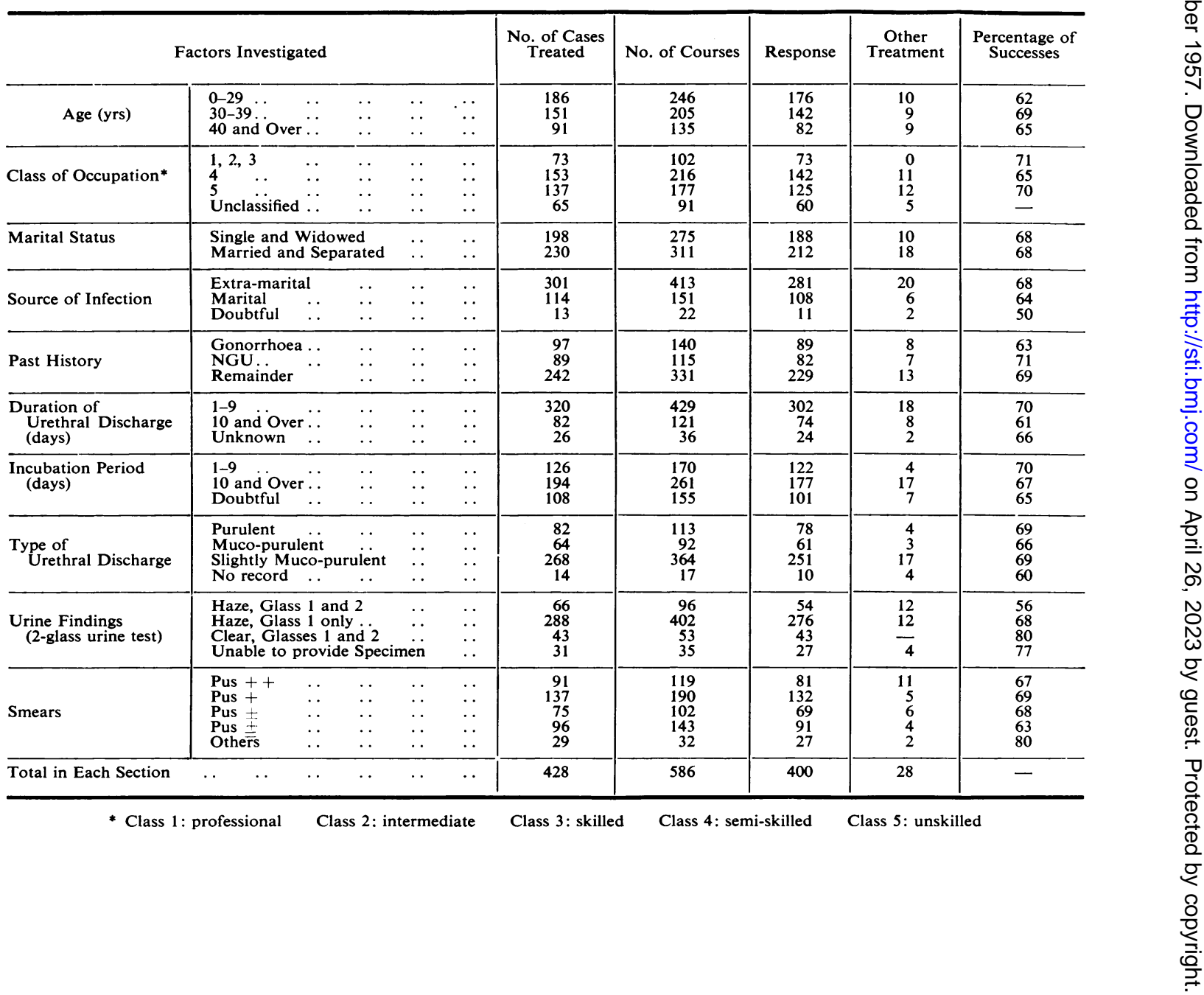


source of infection, past history, incubation period, duration of discharge, type of discharge, urine findings, or the smear results (Table III).

Table III shows that there was no clear indication of who had the better chance of prompt "cure". It is perhaps noteworthy that, although the condition is known to clear spontaneously, the duration of the discharge had no effect. Whether the clinical manifestations were severe or mild did not seem to affect the response to treatment. The data for response was further analysed according to the various types of treatment, but no significant findings were discovered.

Recurrence.-Since the populations in our care are fairly static, because they are suburban, urban, and country people, we found ourselves able to examine the problem of recurrence. During the 5-year period under review and for 6 months afterwards, fifty patients in the study group of 428 reported with a recurrence of the discharge (Table IV).

TABLE IV

ANALYSIS OF 400 "CURED" BY THE PRESCRIBED SCHEDULES OF MORTON AND READ

\begin{tabular}{|c|c|c|c|c|c|c|}
\hline \multirow{2}{*}{\multicolumn{3}{|c|}{ Treatment }} & \multicolumn{2}{|c|}{ Successes } & \multicolumn{2}{|c|}{ Recurrences } \\
\hline & & & No. & Per. cent. & No. & Per cent. \\
\hline $\begin{array}{l}\text { Potassium Citrate } \\
\text { Sulphatriad } \\
\text { Streptomycin } \\
\text { Chloramphenicol } \\
\text { Aureomycin } \\
\text { Terramycin. . }\end{array}$ & $\begin{array}{l}\mathrm{M} \\
\cdots \\
\cdots \\
\cdots \\
\cdots\end{array}$ & $\begin{array}{l}\text { ure } \\
\ldots \\
\cdots \\
\cdots \\
\cdots\end{array}$ & $\begin{array}{r}58 \\
60 \\
73 \\
14 \\
47 \\
148\end{array}$ & $\begin{array}{r}48 \\
55 \\
70 \\
73 \\
76 \\
85\end{array}$ & $\begin{array}{r}3 \\
5 \\
9 \\
2 \\
7 \\
24\end{array}$ & $\begin{array}{r}5 \\
8 \\
12 \\
14 \\
15 \\
16\end{array}$ \\
\hline Total & $\cdots$ & .. & 400 & - & 50 & - \\
\hline
\end{tabular}

Table IV reveals an overall recurrence rate of 12.5 per cent. in the 400 patients successfully treated, or 11.6 per cent. of the total number of 428. The schedules of treatment resulting in the highest success rates were followed by the highest recurrence rates and vice versa; i.e. those who responded most satisfactorily only tended to show recurrence most readily. So far as we know, this feature of recurrence has not been noted before. We are aware that it may apply only to the schedules of treatment which we have prescribed. With the newer antibiotics now in more general use, we feel justified in suggesting that an iatrogenic factor may be contributing to the increasing incidence of NGU.

The average interval between completion of treatment and recurrence was 8 months (range 10 days to 4 years 8 months). In eight cases of recurrence, the prostatic bead had been found normal after the original course of therapy, and in four cases, the prostatic bead was found to be normal at the time of recurrence. 22 patients with recurrence admitted to fresh exposure, with the original consort, or with a new consort, and some of the others admitted bouts of heavy drinking in the weeks before appearance of the urethral discharge, but many gave no clue to the cause of the recurrence. An analysis of the relapse/re-infection group according to the basic details which we were able to provide is shown in Table $\mathrm{V}$ together with the percentage chances of recurrence according to each detail of the host.

TABLE $\mathrm{V}$

PERCENTAGE RECURRENCES ACCORDING TO PERSONAL DETAILS AND CLINICAL FINDINGS

\begin{tabular}{|c|c|c|c|c|}
\hline \multicolumn{2}{|c|}{ Factors Investigated } & \multirow{2}{*}{$\begin{array}{c}\begin{array}{c}\text { Number } \\
\text { of Cases } \\
\text { Treated }\end{array} \\
186 \\
151 \\
91\end{array}$} & \multirow{2}{*}{$\begin{array}{c}\text { Recurrence } \\
28 \\
12 \\
10\end{array}$} & \multirow{2}{*}{$\begin{array}{r}\text { Percentage } \\
\text { Recurrence } \\
15 \\
8 \\
11\end{array}$} \\
\hline Age (yrs) & $\begin{array}{ll}1-29 & \ldots \\
30-39 & \ldots \\
40 \text { and over } .\end{array}$ & & & \\
\hline $\begin{array}{l}\text { Class of } \\
\text { Occupation }\end{array}$ & $\begin{array}{lcc}1,2, & 3 & \ldots \\
\mathbf{4} & \cdots & \ldots \\
\text { Unclassified }\end{array}$ & $\begin{array}{r}73 \\
153 \\
137 \\
65\end{array}$ & $\begin{array}{l}7 \\
22 \\
10 \\
11\end{array}$ & $\begin{array}{r}9 \\
14 \\
8 \\
17\end{array}$ \\
\hline$\underset{\text { Status }}{\text { Marital }}$ & $\begin{array}{l}\text { Married and } \\
\text { Separated } \\
\text { Single and } \\
\text { Widowed }\end{array}$ & $\begin{array}{l}230 \\
198\end{array}$ & $\begin{array}{l}18 \\
32\end{array}$ & $\begin{array}{r}8 \\
16\end{array}$ \\
\hline $\begin{array}{l}\text { Source of } \\
\text { Infection }\end{array}$ & $\begin{array}{lc}\text { Extra-marital } \\
\text { Marital } & \ldots \\
\text { Doubtful } & \ldots\end{array}$ & $\begin{array}{r}301 \\
114 \\
13\end{array}$ & $\begin{array}{r}39 \\
10 \\
1\end{array}$ & $\begin{array}{r}13 \\
9 \\
8\end{array}$ \\
\hline $\begin{array}{l}\text { Past } \\
\text { History }\end{array}$ & $\begin{array}{l}\text { Gonorrhoea } \\
\text { NGU } \quad \cdots \\
\text { Remainder . }\end{array}$ & $\begin{array}{r}97 \\
89 \\
242\end{array}$ & $\begin{array}{l}10 \\
16 \\
24\end{array}$ & $\begin{array}{l}10 \\
18 \\
10\end{array}$ \\
\hline $\begin{array}{l}\text { Duration of } \\
\text { Urethral } \\
\text { Discharge } \\
\text { (days) }\end{array}$ & $\begin{array}{l}1-9 \text {. } \\
10 \text { and over } . \\
\text { Unknown } \ldots\end{array}$ & $\begin{array}{r}320 \\
82 \\
26\end{array}$ & $\begin{array}{r}35 \\
9 \\
6\end{array}$ & $\begin{array}{l}11 \\
11 \\
23\end{array}$ \\
\hline $\begin{array}{c}\text { Incubation } \\
\text { Period } \\
\text { (days) }\end{array}$ & $\begin{array}{l}1-9 . \\
10 \text { and over } . \\
\text { Unknown }\end{array}$ & $\begin{array}{l}126 \\
194 \\
108\end{array}$ & $\begin{array}{l}13 \\
20 \\
17\end{array}$ & $\begin{array}{l}10 \\
10 \\
16\end{array}$ \\
\hline $\begin{array}{l}\text { Type of } \\
\text { Urethral } \\
\text { Discharge }\end{array}$ & $\begin{array}{l}\text { Purulent . } \\
\text { Muco-puru- } \\
\text { lent } \\
\text { Slightly Muco- } \\
\text { purulent .. } \\
\text { No Record .. }\end{array}$ & $\begin{array}{r}82 \\
64 \\
268 \\
14\end{array}$ & $\begin{array}{r}10 \\
12 \\
28 \\
0\end{array}$ & $\begin{array}{l}12 \\
19 \\
10 \\
\end{array}$ \\
\hline $\begin{array}{l}\text { Urine } \\
\text { ( } 2-\text { glass } \\
\text { urine } \\
\text { test) }\end{array}$ & $\begin{array}{l}\text { Haze, } \\
\text { Glasses } 1 \\
\text { and } 2 \\
\text { Haze, Glass } 1 \\
\text { only } \ldots \\
\text { Clear, Glasses } \\
1 \text { and } 2 \ldots \\
\text { Un a b le t o } \\
\text { p r o v i d e } \\
\text { Specimen }\end{array}$ & $\begin{array}{r}66 \\
288 \\
43 \\
31\end{array}$ & $\begin{array}{r}9 \\
33 \\
3 \\
\\
5\end{array}$ & $\begin{array}{r}14 \\
11 \\
7 \\
16\end{array}$ \\
\hline Smears & $\begin{array}{ll}\text { Pus } t+ & \ldots \\
\text { Pus } t & \ldots \\
\text { Pus } \pm & \ldots \\
\text { Pus } \pm & \ldots \\
\text { Others } & \ldots\end{array}$ & $\begin{array}{r}91 \\
137 \\
75 \\
96 \\
29\end{array}$ & $\begin{array}{r}10 \\
18 \\
15 \\
6 \\
1\end{array}$ & $\begin{array}{r}11 \\
13 \\
20 \\
6 \\
3\end{array}$ \\
\hline Total in Each & tion & 428 & 50 & 一 \\
\hline
\end{tabular}

The youngest age group showed a higher incidence of recurrences. This is also noted amongst 
the "unmarried" group, and would appear to correlate with the higher incidence of recurrence where the source is extramarital.

An analysis of the "married" men showed equal recurrence rates with marital and extramarital sources. Recurrence is greatest amongst those with a past history of NGU. The clinical findings, whether severe or mild, give no indication as to the possibility of reappearance of urethral discharge.

Examination of Consorts.-The consorts of 78 of the 428 men were examined. 59 of them were found to be clinically normal, and showed no evidence of fungus infection or of Trichomonas vaginalis. Of the remaining nineteen, five were harbouring Odium albicans, and six were infested with Trichomonas vaginalis. Two of the women had gonorrhoea and were contacts of men who developed NGU after treatment of their gonorrhoea. One female contact had vulvar and vaginal warts, and five had cervical erosions. Those with local conditions were treated by local therapy, and seven of them, together with nineteen from the clinically-normal group, received an empirical course of therapy, similar to that to which the appropriate male contact had responded. Three (11 per cent.) of the men had a subsequent recurrence, and seven ( 13.5 per cent.) of the men with untreated female contacts had a recurrence.

\section{Summary}

(1) 428 cases of NGU were observed for varying periods up to 3 months after various schedules of treatment.

(2) The reponse to the various types of treatment followed the accepted pattern and forms a fair basis on which to study recurrence.

(3) The inability of many workers to determine the cause of NGU led us to make a retrospective study of our material, seen over a 5-year period, to ascertain whether such factors as age, occupation, marital status, past history, and clinical symptoms gave a hint as to the part played by the host in response to therapy, and in recurrence of NGU.

(4) Neither these factors nor source of infection, duration of urethral discharge, duration of incubation period, type of urethral discharge, urine examination, and smear findings, gave us a lead in deciding the best form of therapy in any individual case.

(5) We found recurrences to be slightly commoner in younger, single men, and those with a previous history of NGU had increased chances of recurrence. Occupational classification, source of infection in the married, duration of discharge, incubation period, type of urethral discharge, urine examination, and smear findings, gave no indication as regards prognosis or chance of recurrence. Empirical treatment of the patients' consorts did not seem to lessen the chance of recurrence. but we feel that this aspect should receive further attention.

(6) The overall recurrence rate was $11 \cdot 6$ per cent. of cases. There is a definite tendency for recurrence to increase with "better" forms of treatment. Whether immunity responses are involved would appear to be open to discussion. We feel that the increasing use of the newer antibiotics over the last few years may have contributed to the rising incidence of the condition.

\section{REFERENCES}

Abraham, E. P., and Duthie, E. S. (1946). Lancet, 1, 455.

Auckland, G., and Preston, W. J. (1954). British Journal of Venereal Diseases, 30, 81 .

Coutts, W. E. (1948). Ibid., 24, 109.

Ford, D. K. (1956). Ibid,. 32, 184

Freed, L. F. (1945). S. Afr. med. J., 19, 73.

(1948). Ibid., 22, 223.

Gartman, E., and Leibovitz, A. (1955). British Journal of Venereal Diseases, 31, 92.

Grimble, A., and Csonka, G. W. (1955), Ibid, 31, 228.

Harkness, A. H. (1953). British Journal of Venereal Diseases, 29, 134. Kershaw, P. S., and Lindsay, J. G. (1956). J. roy. Army med. Cps., $102,56$.

Kirby, R. A., Bucca, M. A., and Thayer, J. D. (1950). Amer. J. med. Technol., 16, 113 .

Lanceley, F., and McEntegart, M. G. (1953). Lancet, 1, 668.

Lancet (1954). Annotation, 2, 695.

Liston, W. G., and Lees, R. (1940). British Journal of Venereal Diseases, 16. 34

Lyall, T. (1953). Ibid., 29, 151

Melén, B., and Linnros, B. (1952). Acta derm.-venereol. (Stockh.), 32, 77.

Ministry of Health (1952-56). Reports of Chief Medical Officer. H.M.S.O., London.

Nicol, C. S., and Edward, D. G. ff. (1953). British Journal of Venereal Diseases, 29, 141

Prebble, E. E. (1957). Ibid., 33, 43.

Sorel, C. (1954). "Symposium sur les urétrites non-gonococciques, M. W.

Willcox, R. R. (1954a). Brit. med.J., 1, 13.

Willcox, R. R. (1954a). Brit.

(1956). British Journal of Venereal Diseases, 32, 115. Wolf, F. S., Thoshinsky, M. J., Chodosh, S., and Arrington, J. O.
(1956). U.S. armed Forces med. J., 7, 852. 